\title{
URGENSI PELAYANAN PRIMA DALAM PENINGKATAN MUTU PEMBELAJARAN DI LEMBAGA PENDIDIKAN ISLAM
}

\author{
Nurul Yaqien \\ e-mail : nyaqien@mpi.uin-malang.ac.id \\ FITK UIN Maulana Malik Ibrahim Malang
}

\begin{abstract}
Every education institution especially Islamic education institution properly provides the best learning services in developing the effort of student quality. Services in education is an absolutely student needs, especially services in developing learning quality, moreover seeing the needs of competitive era. Student's competence will compete with another competence both in own country and global world particularly in ASEAN region. To undertake the best services in every Islamic education institution, each circle academician of education needs to know the best service concepts. By knowing it that is expected all circle academicians could provide the optimal services for implementing qualified learning. The existence of qualified learning that expected to be able to make excellent generation in all aspects both in religion and general.
\end{abstract}

Keyword: Excellent Service, Quality Improvement, Learning

\section{Abstrak}

Setiap lembaga pendidikan terutama lembaga pendidikan Islam selayaknya memberikan layanan pembelajaran yang terbaik dalam upaya meningkatkan mutu siswanya. Layanan dalam pendidikan ini merupakan sesuatu yang mutlak diperlukan oleh siswa, terutama layanan dalam peningkatan mutu pembelajaran. Terlebih lagi, melihat kebutuhan zaman yang semakin kompetitif. Kompetensi siswa akan bersaing dengan kompetensi siswa yang lainnya baik dalam negeri sendiri maupun dalam dunia global terutama dalam kawasan ASEAN. Untuk dapat menjalankan layanan prima dalam setiap lembaga pendidikan Islam, maka setiap civitas akademika pendidikan perlu mengetahui konsep layanan prima. Dengan pengetahuan tersebut diharapkan civitas akademika dapat memberikan layanan yang optimal demi terselenggaranya pembelajaran yang bermutu. Adanya pembelajaran yang bermutu itulah diharapan akan mampu mencetak generasi yang unggul dalam segala bidang baik agama maupun umum.

Kata kunci: Pelayanan Prima, Perbaikan kualitas, Pembelajaran.

\section{Pendahuluan}

Manusia pada dasarnya memiliki kebutuhan untuk hidup bahagia dimanapun ia berada. Kebahagiaan itu akan sulit untuk dicapai manakala manusia tidak memiliki ilmu. Dalam dunia pendidikan, siswa adalah manusia yang berusaha untuk menuntut ilmu demi masa depannya. Siswa memerlukan layanan pembelajaran yang bermutu. Siswa akan sangat terbantu manakala diberikan layanan sebaik-baiknya untuk memudahkannya dalam meraih ilmu yang dicita-citakan. Oleh karena itulah, siswa membutuhkan banyak bantuan dari orang lain terutama dari seluruh civitas akademika termasuk guru dan tenaga administrasi. Bantuan layanan yang terbaik dalam proses pembelajaran akan menjadikan siswa memiliki kompetensi yang unggul yang dapat dibanggakan oleh lembaga pendidikan itu sendiri.

Pelayanan prima atau dalam bahasa inggris "excellent service" yang secara bahasa berarti pelayanan terbaik atau sangat baik. Dikatakan sangat baik atau terbaik karena sesuai dengan standar pelayanan yang berlaku atau standart 
pelayanan yang dimiliki oleh sebuah instansi/lembaga. Jika pelayanan prima dikaitkan dengan pelayanan pembelajaran, berarti pemberian pelayanan prima kepada siswa merupakan perwujudan dari kewajiban lembaga pendidikan terhadap siswanya. Terutama dari pelayanan pembelajaran baik dari pendidik maupun dari tenaga kependidikan sekolah dan seluruh civitas akademika sekolah yang ada. Adanya proses pembelajaran dengan layanan yang terbaik akan memberikan dampak positif terhadap peserta didik maupun dampak terhadap harapan orangtua akan pendidikan anak yang terbaik. Setiap orangtua dapat dipastikan membutuhkan layanan yang terbaik dari lembaga pendidikan untuk memberikan layanan kepada putra-putrinya dalam meraih cita-citanya. Terlebih lagi dengan adanya ASEAN Free Trade Asia 2015 menjadikan tantangan dunia pendidikan yang semakin kompetitif.

Adanya ASEAN Free Trade Area (AFTA) yang dimulai pada tahun 2015 merupakan tantangan tersendiri bagi bangsa Indonesia untuk bersaing dalam segala segi, baik ekonomi maupun jasa. Persaingan dalam hal jasa saat ini sudah sangat kompetitif. Persaingan tresebut diantaranya dalam hal pendidikan. Pendidikan merupakan salah satu bidang yang ikut serta dalam persaingan antar negara-negara di kawasan ASEAN. Kualitas atau mutu pendidikan bangsa Indonesia dalam hal ini akan diuji kompetensinya dengan kualitas atau mutu pendidikan dari negara-negara ASEAN. Apabila kualitas pendidikan bangsa Indonesia kurang kompetitif dari segi output atau outcome maka pendidikan ini akan termarginalkan dengan sendirinya. Ketidaksiapan suatu bangsa dalam menghadapi perkembangan zaman dengan sendirinya akan menjatuhkan bangsa itu sendiri dalam persaingan global yang kompetitif (Siagian: 2014). Dengan adanya layanan prima dalam pendidikan terutama layanan pembelajaran dengan sendirinya akan menghasilkan mutu atau kualitas output atau outcome pendidikan yang baik pula. Oleh karena itu, layanan prima menjadi urgen atau sangat dibutuhkan dalam rangka mengelola mutu pembelajaran dan pendidikan menjadi lebih baik.

\section{Pembahasan}

1. Definisi Layanan Prima

Dalam kaitannya dengan pembahasan layanan prima maka ada beberapa definisi yang perlu di jelaskan, yaitu tentang layanan itu sendiri. Layanan dalam Kamus Besar Bahasa Indonesia adalah usaha melayani kebutuhan orang lain (Tim PKBBI, 1999: 646). Layanan pada dasarnya adalah kegiatan yang ditawarkan kepada konsumen atau pelanggan yang dilayani, yang bersifat tidak berwujud dan tidak dapat dimiliki. Secara Istilah (dalam Simanjuntak: 2011) pelayanan adalah suatu kegiatan atau suatu urutan kegiatan yang terjadi dalam interaksi langsung dengan manusia atau mesin secara fisik untuk menyediakan kepuasan konsumen. Ada juga yang mengarikan pelayanan sebagai sesuatu yang dapat diperjualbelikan dan bahkan tidak dapat dihilangkan.

Pengertian lebih luas mengenai pelayanan ini disampaikan Daviddow dan Uttal dalam (Sutopo dan Suryanto: 2003) yaitu pelayanan merupakan usaha apa saja yang dapat meningkatkan kepuasan pelanggan. Sedangkan istilah Prima dalam Kamus Bahasa Indonesia adalah pertama / sangat baik/utama (KBI, org). Sehingga layanan prima merupakan usaha melayani kebutuhan orang lain dengan memperhatikan "kepuasan pelanggan" yang utama atau kepuasan pelanggan terkait layanan harus diutamakan.

Kata "kepuasan pelanggan" pada dasarnya lebih dekat dengan makna kemudahan dalam mengakses segala kebutuhan yang diperlukan oleh pelanggan. Dalam kaitannya dengan layanan pendidikan, peserta didik merasa puas apabila kesulitan kesulitan dalam proses pembelajaran mendapatkan perhatian dari seluruh civitas akademik. Perhatian dan pemberian layanan inilah yang menjadikan para pelanggan merasa senang dan akhirnya munculah kata "puas" atau perasaan "puas" mendapatkan 
pelayanan yang baik, terutama terkait dengan kemudahan dalam proses pembelajaran. Kepuasan terhadap pelanggan inilah yang merupakan bagian yang diinginkan dan terpenting dengan adanya pelayanan prima dalam system manajemen modern saat ini.

Pengertian layanan prima tersebut di atas menunjukkan pentingnya pelayanan yang diberikan kepada pelanggan untuk mewujudkan tujuan organisasi tertentu. Dalam hal bisnis pelayanan prima mempunyai peranan penting baik dari sisi pelanggan internal maupun pelanggan eksternal, karena sangat berpengaruh pada loyalitas pelanggan kepada organisasi/perusahaan. Demikian juga jika pelayanan prima ini dilakukan oleh pihak non-komersil atau pemerintah dalam hal ini adalah pendidikan. Pelayanan prima dalam dunia pendidikan merupakan sesuatu hal yang pokok yang tidak dapat diabaikan oleh lembaga pendidikan manapun. Apabila ada lembaga pendidikan yang mengabaikan pentingnya layanan dapat dipastikan lambat-laun pendidikan tersebut akan termarginalkan oleh pelanggannya sendiri, baik pelanggan internal maupun pelanggan eksternal.

Pelanggan internal adalah orangorang yang terlibat dalam proses produksi barang atau jasa yang ditawarkan perusahaan. Pelanggan internal diantaranya para karyawan atau dalam pendidikan yaitu para guru dan tenaga pendidikan. Dalam dunia bisnis ada semboyan para pelaku bisnis yang menyatakan: "Bila pegawai tidak terpuaskan, anda tidak akan mempunyai pelanggan yang terpuaskan." Maka dengan melaksanakan pelayanan prima di lingkungan internal, akan menunjang kelancaran proses produksi barang atau pembentukan jasa (standart pelayanan dalam pendidikan). Keberhasilan pembudayaan pelayanan prima di lingkungan internal, akan menjadi tonggak dasar dalam mewujudkan pelayanan prima di lingkungan eksternal. Dalam dunia pendidikan pelanggan dalam lingkungan eksternal adalah orangtua peserta didik.

\section{Karakteristik Pelayanan Prima}

Untuk dapat menerapkan pelayanan prima dalam pendidikan terutama dalam pembelajaran maka perlu diketahui karakteristik pelayanan prima terlebih dahulu. Berikut ini ada beberapa karakteristik yang menunjukkan adanya pelaksanaan layanan prima yang dapat diketahui dalam setiap kegiatan. Pengetahuan karakteristik ini sangat penting untuk mengetahui apakah layanan yang diberikan sudah sesuai dengan karakteristik layanan prima ataukah masih jauh dari kata layanan prima. Pengetahuan karakteristik ini menjadi penting agar pelanggan merasa puas atas jasa yang ditawarkan. Setiap kegiatan yang menunjukkan layanan prima akan di tunjukkan oleh pribadi-pribadi yang prima pula.

Adapun pelayanan prima dapat ditunjukkan dengan adanya indikatorindikator prilaku para pegawai berikut ini:

a. Pelayanan yang ramah

Pelayanan yang ramah merupakan salah satu kunci awal dalam melayani setiap pelangan yang datang. Pelayanan yang ramah ini ditunjukkan dalam prilaku pegawai yang murah senyum. Dalam hal pendidikan indikator tersebut akan muncul pada perlakuan guru dan pegawai ketika awal pendafaran siswa baru. Selain murah senyum juga di tunjukkan dengan memberikan kemudahan dan bantuan dalam proses seleksi awal.

b. Bersikap sopan dan penuh hormat

Setiap pelanggan yang menggunakan instasi atau lembaga dalam memenuhi hajatnya harus di sambut dengan kata-kata yang sopan dan penuh hormat. Sehingga tidak dibenarkan apabila menggunakan katakata yang bernada sombong dan tidak menghormati para pelanggan yang akan menggunakan jasa tersebut. Dalam pelaksanaan pembelajaran tidak selayaknya seorang guru berkata yang kurang sopan pada siswanya. Seorang guru yang merupakan pelaku dalam pemberian pelayanan pada siswanya 
hendaknya mengajarkan atau membelajarkan siswa dengan penuh kasih sayang sehingga siswa merasa nyaman dan mudah dalam memperoleh ilmu yang diinginkannya.

c. Tampil yakin

Pelayanan prima memiliki ciri tampil dengan penuh keyakinan atau percaya diri dan tidak rendah diri. Pelayanan prima berusaha semaksimal mungkin menumbuhkan keyakinan para pelanggan bahwa instansi ini akan memberikan solusi terhadap masalah yang dihadapi. Keyakinan pelanggan ini akan terbentuk manakala pegawai melayani dengan penuh keyaninan dalam melayani sehingga pelanggan menjadi tenang. Dalam proses pembelajaran hendaknya seorang guru membelajarkan materi dengan profesioanal. Professional dalam bidang metodologinya maupun penguasaan materinya.

d. Memberikan kesan ceria

Pelayanan prima akan memberikan kesan ceria atau bahagia pada setiap pelanggan yang dihadapinya. Kesan ceria ini akan menjadikan pelanggan tidak bosan apabila menghadapi kesulitan dalam instasinya untuk meminta bantuan dalam menyelesaikan masalah yang dihadapinya. Dalam pendidikan kesan ceria setiap guru dan para pegawainya akan mencitakan rasa senang dan akan sangat dalam proses pembelajarannya

\section{e. Berpenampilan rapi}

Pemberi pelayanan hendaknya berpenampilan yang meyakinkan dan rapi. Tampilan yang rapi akan memberikan pengaruh pada mutu layanan itu sendiri. Penampilan yang rapi juga akan memberikan kesan professional pada setiap tindakan yang dilakukan dalam lembaga atau instasi yang bersangkutan. Dalam pendidikan seorang guru dan karyawan harus memberikan penampilan yang rapi dalam setiap melakukan kegiatan di lembaganya. Kesan rapi inilah yang akan membawa lembaga tersebut menjadi professional dalam proses pembelajarannya.

f. Senang bergaul

Pelayanan prima memiliki ciri senang bergaul. Senag bergaul yaitu senang terhadap pelanggan yang datang atau pelanggan yang sudah ada. Senang dalam arti melayani kebutuhan pelanggan. Dalam konteks pendidikan senang bergaul yaitu senang dalam membelajarkan materi pada siswa dan juga senang dalam menyelesaikan masalah yang dihadapi oleh siswa dam proses pembelajarannya.

g. Mudah memaafkan

Pelayanan prima memiliki ciri mudah memaafkan. Dalam pelayanan prima pelanggan terkadang melakukan kesalahan yang merugikan instansi. Kemarahan pada saat tersebut sebenarnya sudah tepat pada tempatnya, akan tetapi pelayanan prima akan selalu memaafkan setiap kesalahan pelanggan yang dilakukan tanpa sengaja. Perlakukan ini akan menimbulkan atau memberikan kesan ramah dalam melayani pelanggan. Dalam konteks pendidikan siswa juga pasti melakukan kesalahan. Kesalahan siswa ditinjau dari adanya pelayanan prima akan memberikan maaf kepada siswa yang melakukan kesalahan tersebut. Kesalahan siswa dapat dipastikan ada penyebab yang menimbulkannya. Oleh karena itu, pelayanan prima akan memberikan solusi atas kesalahan yang telah diperbuatnya. Pemberian solusi akan menjadikan siswa tidak merasa di adili oleh lembaga akan tetapi di bantu dalam menyelesaikan masalahnya.

h. Senang belajar dari orang lain

Pelayanan prima di tunjukkan dengan prilaku senang belajar pada orang lain. Maksud ciri tersebut adalah seorang pegawai hendaknya selalu belajar dari pengalaman orang lain. Selalu senang belajar merupakan salah satu kunci agar pegawai tidak melakukan kesalahan dua kali pada kejadian yang sama. Dalam pendidikan 
seorang guru atau pegawai hendaknya menerima masukan dari stakeholder yang memberikan usulan terkait pembelajaran yang bermutu. Masukan tersebut akan dikaji ulang untuk dapat memberikan layanan yang lebih baik pada hari-hari yang lain.

i. Senang pada hal-hal yang etis dan wajar

Pelayanan prima di tunjukkan dengan pada hal-hal yang etis dan wajar. Prilaku etis dan wajar adalah prilaku yang umumnya di sukai orang banyak, atau prilaku yang tidak akan menimbulkan masalah jika dilakukan. Dalam pendidikan prilaku etis dan wajar ini sangat penting dilakuka oleh setiap guru dan siswa dalam proses pembelajarannya. Prilaku yang tidak etis baik oleh guru dan pegawai akan menjadikan masalah tersendiri yang akan dihadapi oleh lembaga pendidikan itu sendiri.

j. Pandai menyenangkan orang lain

Pelayanan prima ditunjukkan oleh prilaku pandai menyenangkan orang lain. Maksud dari pandai menyenangkan oranglain adalah memberikan layanan khusus terkait hiburan dan fasilitas tambahan. Dalam layanan pendidikan prilaku menyenagkan orang lain adalah dengan memberikan hadiah atau penghargaan bagi siswa yang memiliki perstasi dalam pembelajarannya. (Ciputra, 2015)

Sejalan dengan hal tersebut, Norman, (1991:14) menyatakan bahwa karakteristik pelayanan dari sifatnya meliputi sebagai berikut:

a. Pelayanan bersifat tidak dapat diraba, pelayanan sangat berlawanan sifatnya dengan barang jadi.

Pada karakteristik pertama pelayanan sifatnya berbeda dengan barang jadi. Kalau barang jadi pelanggan akan puas ketika barang tersebut sesuai dengan yang diharapkan. Sedangkan pelayanan ini merupakan pemberian sikap dan bantuan yang diberikan kepada pelanggan baik internal maupun eksternal. Dengan adanya pemberian sikap dan bantuan pada pelanggan ini diharapkan pelanggan akan merasa senang dan "puas" terhadap layanan yang telah di berikan pada pelanggan. Dalam hal pendidikan, pemberian layanan pembelajaran akan sangat membantu siswa dalam mempelajari, memahami, dan mempraktekkan apa yang telah di ajarkan oleh seorang guru. Dengan pelayanan yang diperoleh siswa akan menjadi kompeten terhadap materi yang di ajarkan oleh seorang guru.

b. Pelayanan pada kenyataannya terdiri dari tindakan nyata dan merupakan pengaruh yang bersifat tindakan sosial.

Pelayanan yang sifatnya bantuan merupakan tindakan nyata yang dilakukan oleh instansi atau lembaga untuk menjadikan para pelanggan memiliki image baik terhadap instansi/lembaga tersebut. Image ini sangat penting untuk menumbuhkan kepercayan para pelanggan untuk kembali menggunakan jasa instansi atau lembaga tersebut dalam upaya menyelesaikan kebutuhan hidupnya. Dalam konteks pendidikan masyarakat akan mempercayakan pembelajaran anaknya pada lembaga tersebut.

c. Kegiatan produksi dan konsumsi dalam pelayanan tidak dapat dipisahkan secara nyata, karena pada umumnya terjadi dalam waktu dan tempat bersamaan.

Kegiatan dalam palayanan jika dibandingkan dengan kegiatan dalam perusahaan barang memang sangat berbeda. Pelayanan dalam bidang jasa antara produksi dan konsumsi memang tidak dapat dipisahkan secara nyata. Kesulitan pemisahan ini karena kegiatannya dilakukan dalam tempat dan waktu yang bersamaan. Seperti kegiatan dalam pembelajaran di kelas. Seorang guru bahasa Inggris selain memproduksi atau kata lain yang lebih tepat membelajarkan siswa terhadap materi bahasa Inggris, tertentu siswa juga menggunakan materi bahasa Inggris tersebut yang telah dikuasai 
dalam kehidupan sehari-hari guna melatih diri menjadi pribadi yang trampil dalam materi tersebut, sehingga menjadi manusia unggul dalam bidangnya.

3. Tujuan Layanan Prima

Dalam pembahasan urgensi layanan prima ini, hakikat layanan prima tergantung pada tujuan organisasi itu sendiri didirikan. Jika tujuan organisasi tersebut berfokus pada layanan maka tujuan layanan organisasi itu menjadi fokus utama. Seperti produk dari organisasi pemerintahaan yaitu pelayanan masyarakat / publik service, maka layanan prima menjadi fokus utamanya. Pelayanan prima tersebut diberikan untuk memenuhi hak masyarakat secara umum. Kegiatan pelayanan pada dasarnya menyangkut pemenuhan kebutuhan suatu hak yang melekat pada setiap orang, baik secara pribadi maupun kelompok. Teori ini sesuai dengan pendapat Moenir (1998) yang menjelaskan bahwa hak atas pelayanan itu sifatnya universal, berlaku bagi siapa saja yang berkepentingan atau yang membutuhkan atas hak tersebut.

Keputusan

Menteri

Pendayagunaan Aparatur Negara No 63/KEP/M.PAN7/2003, tentang Pedoman Umum Penyelenggaraan Pelayanan Publik, yang disebut pelayanan publik adalah "Segala kegiatan pelayanan yang dilaksanakan oleh penyelenggara pelayanan publik sebagai upaya pemenuhan kebutuhan penerima layanan maupun pelaksanaan ketentuan peraturan perundang-Undangan (Menpan: 2003). Pengertian pelayanan publik tersebut menunjukkan sebagai serangkaian aktivitas yang dilakukan oleh para petugas untuk memenuhi kebutuhan warga yang membutuhkan layanan. Pentingnya layanan publik tersebutakan selalu menjadi sorotan dan perhatian masyarakat baik pengguna layanan secara langsung maupun tidak. Tidak hanya barang yang dihasilkan dalam pelayanan publik, tetapi juga jasa dalam hal memberikan pelayanan administrasi terhadap masyarakat.

Hasil pengkajian para ahli menunjukkan pentingnya pelayanan prima kepada pelanggan dengan mengembangkan konsep Total Quality Service (TQS). Tujuan dari TQS adalah mewujutkan tercapainya kepuasan pelanggan, memberikan tanggung jawab kepada setiap orang dan melakukan perbaikan pelayanan secara berkesinambungan. Konsep TQS menurut Tjipto (1997), yaitu:

1) Berfokus kepada Pelanggan

Prioritas utama adalah mengidentifikasi keinginan, kebutuhan dan harapan pelanggan. Selanjutnya dirancang sistem yang dapat memberikan jasa atau layanan tertentu yang memenuhi keinginan pelanggan. Pelanggan akan menjadi puas manakala mendapat layanan sesuai dengan keinginan, kebutuhan dan harapan pelanggan.

2) Keterlibatan Pegawai secara Menyeluruh

Semua pihak yang terkait dengan upaya peningkatan pelayanan harus dilibatkan secara total menyeluruh. Karena itu, pimpinan harus dapat memberikan peluang perbaikan kualitas terhadap semua pegawai. Selain itu, kepemimpinan harus pula memberikan kesempatan berpartisipasi kepada semua pegawai yang ada dalam organisasi, serta memperdayakan pegawai atau karyawan dalam merancang dan memperbaiki barang, jasa, sistem dan organisasi.

3) Sistem Pengukuran

Komponen dalam sistem pengukuran terdiri hal-hal berikut ini:

a. Menyusun standar proses dan produk

b. Mengidentifikasi ketidaksesuaian dan mengukur kesesuaiannya dengan keinginan pelanggan

c. Mengoreksi penyimpangan dan meningkatkan kinerja.

4) Perbaikan Kesinambungan.

a. Memandang bahwa semua pekerjaan sebagai suatu proses

b. Mengantisipasi perubahan keinginan, kebutuhan dan harapan para pelanggan.

c. Mengurangi waktu siklus proses produksi dan distribusi.

d. Dengan senang hati menerima umpan balik dari pelanggan. (Dauzy : 2009) 
Dalam dunia pendidikan, pada hakikatnya tujuan pelayanan merupakan hal yang pokok dalam organisasi tersebut. Organisasi pendidikan sesuai dengan pengertian pendidikan itu sendiri, merupakan organisasi yang lebih menekankan pada pelayanan. Pendidikan menurut undang-undang No 20 tahun 2003 merupakan usaha sadar dan terencana untuk mewujudkan suasana belajar dan proses pembelajaran agar peserta didik secara aktif mengembangkan potensi dirinya untuk memiliki kekuatan spiritual keagamaan, pengendalian diri, kepribadian, kecerdasan, akhlak mulia, serta keterampilan yang diperlukan dirinya, masyarakat, bangsa dan negara. Berdasarkan konsep layanan dan pengertian pendidikan tersebut dapat disimpulkan bahwa layanan pendidikan merupakan suatu kegiatan atau tindakan atau layanan yang diberikan oleh penyelenggara pendidikan/lembaga pendidikan baik berupa barang ataupun jasa yang menghasilkan manfaat bagi penerima layanan atau siswa dalam rangka mencetak generasi yang memiliki kompetensi yang kompetitif.

Adapun tujuan pelayanan prima adalah memberikan pelayanan yang dapat memenuhi dan memuaskan pelanggan, dalam hal ini adalah siswa itu sendiri. Pelayanan prima di sekolah adalah termasuk juga dalam proses pembelajarannya, jadi bukan hanya diluar proses pembelajaran. Guru haruslah melakukan proses pembelajaran yang bisa memuaskan siswa-siswi tersebut, artinya siswa bisa menelaah dan memahami apa yang dijelaskan oleh gurunya. Demi terwujudnya hal itu, guru haruslah kreatif dalam melakukan proses pembelajaran, dimulai pada saat guru merancang rencana pembelajaran (mulai dari merumuskan tujuan belajar, metode belajar, dan teknik serta evaluasi pembelajaran).

Dalam dunia pendidikan layanan yang baik dalam pembelajaran akan memberikan kepuasan tersendiri pada diri pelanggan diantaranya:
1) Pelanggan akan bercerita pada teman, saudara, keluarga bahwa ia merasa senang atas pelayanan yang diberikan oleh sekolah yang ia pilih.

2) Pelanggan akan mempercayai setiap proses pembelajaran yang diadakan di sekolah tersebut

3) Pelanggan berupaya untuk memilih pendidikannya secara turun menurun dalam keluarganya pada lembaga pendidikan tersebut.

4) Pelanggan ingin mengajak siapa saja yang mau belajar dan akan memperoleh apa yang diinginkan.

5) Pelanggan merasa senang dengan pendidikan yang diselenggarakan yang dapat menimbulkan semangat belajar yang tinggi.

6) Pelanggan merasa kesulitan belajarnya dapat dilayani dengan baik sehingga dapat solusi atas kesulitan yang dihadapinya. dan lain lain.

\section{Urgensi Mutu Pembelajaran}

Secara umum, setiap produk membutuhkan mutu yang baik. Produk yang bermutu merupakan sebuah keniscayaan atau fitrah yang diinginkan oleh setiap mmanusia. Begitupun setiap jasa layanan juga memerlukan layanan yang bermutu atau layanan prima. Begitu pentingnya mutu bagi setiap orang sehingga ia rela mengitari kota/desa berhari-hari hanya untuk mencari sebuah produk atau jasa yang terbaik. Prilaku tersebut menunjukkan adanya fitrah dalam diri setiap manusia untuk mendapatkan produk atau jasa yang berkualitas.

Dalam bidang jasa pendidikan, pembahasan mutu pembelajaran tidak terlepas dari adanya manajemen peningkatan mutu itu sendiri. Manajemen peningkatan mutu adalah gambaran dan karakteristik menyeluruh dari upaya dan proses organisasi untuk menciptakan jasa yang menunjukkan kemampuannya dalam memuaskan kebutuhan pembelajaran yang diharapkan. Untuk itu manajemen peningkatan mutu meniscayakan semua layanan organisasi agar menfokuskan diri pada tujuan yang telah ditetapkan. 
Dalam konteks jasa pendidikan, mutu pembelajaran hakikatnya sangat berkaitan dengan manajemen peningkatan mutu yang mencakup tiga hal pokok yaitu: input, proses, dan output pendidikan. Meskipun sentral layanan pendidikan adalah output secara umum dan lulusan secara khusus, namun input pendidikan akan sangat mempengaruhi proses pembelajaran. Input yang kurang baik atau di bawah standar akan menghasilkan keluaran yang kurang maksimal. Walaupun tidak secara mutlak input yang kurang baik menghasilkan keluaran yang kurang baik, akan tetapi sedikit banyak akan mempengaruhi proses yang menjadikan hasil pembelajaran kurang maksimal.

Mutu lulusan itu sendiri sangat terkait dengan mutu input, proses dan output. Ketiganya tidak dapat dipisahkan satu dengan yang lain. Input pendidikan adalah segala sesuatu yang harus tersedia karena dibutuhkan untuk berlangsungnya proses. Sesuatu yang dimaksud berupa sumberdaya dan perangkat lunak serta harapan-harapan sebagai pemandu bagi berlangsungnya proses, diantaranya meliputi, 1) siswa: kesiapan dan motivasi belajarnya, 2) guru: kemampuan profesional, moral kerjanya (kemampuan personal), dan kerjasamanya (kemampuan sosial). 3) kurikulum: relevansi konten dan operasionalisasi proses pembelajarannya, 4) dan, sarana dan prasarana: kecukupan dan keefektifan dalam mendukung proses pembelajaran, 5) Masyarakat (orang tua, pengguna lulusan, dan perguruan tinggi): partisipasinya dalam pengembangan program-program pendidikan sekolah. (Depdiknas, 2002:7).

Untuk menghasilkan output yang baik maka mutu komponen-komponen tersebut di atas menjadi fokus perhatian / layanan sekolah. Secara lebih rinci dapat disebutkan input sumberdaya meliputi sumberdaya manusia (kepala sekolah, guru termasuk guru BP, karyawan, siswa) dan sumberdaya selebihnya (peralatan, perlengkapan, uang, bahan, dan sebagainya). Input perangkat lunak meliputi struktur organisasi sekolah, peraturan perundang-undangan, deskripsi tugas, rencana, program, dan sebagainya. Input harapan berupa visi, misi, tujuan, dan sasaran yang ingin dicapai oleh sekolah. Kesiapan input sangat diperlukan agar proses dapat berlangsung dengan baik. Oleh karena itu, tinggi rendahnya mutu input data diukur dari tingkat kesiapan input. Makin tinggi tingkat kesiapan input, maka semakin tinggi pula mutu input tersebut (Depdiknas, 2002:7).

Proses pembelajaran merupakan upaya untuk merubah sesuatu menjadi sesuatu yang lain. Sesuatu yang berpengaruh terhadap berlangsungnya proses perubahan disebut adalah input, sedang sesuatu dari hasil proses disebut output. Dalam pendidikan bersekala mikro (tingkat sekolah), proses yang dimaksud adalah proses pengambilan keputusan, proses pengelolaan kelembagaan, proses pengelolaan program, proses belajarmengajar, dan proses monitoring dan evaluasi, dengan catatan bahwa proses belajar mengajar memiliki tingkat kepentingan tertinggi dibandingkan dengan proses-proses lainnya.

Output pendidikan akan dapat dikatakan bermutu manakala proses pembelajarannya juga bermutu. Sehingga dapat dikatakan bahwa output pendidikan merupakan hasil dari layanan kinerja sekolah. Kinerja sekolah dalam hal proses pembelajaran dapat dilihat dan diukur dari kualitasnya, efektifitasnya, produktifitasnya, inovasi pembelajaranya, moral kerjanya dan lain sebaginya. Output pendidikan dapat juga dikatakan bermutu, jika prestasi sekolah khususnya prestasi peserta didik dalam bidang akademik maupun non akademik menunjukkan pencapaian yang tinggi dalam kancah nasional maupun ASEAN.

Adanya masyarakat ekonomi ASEAN yang dimulai tahun 2015, mutu menjadi isu yang sangat penting dalam dunia pendidikan seperti halnya organisasi yang menfokuskan perhatiannya dalam pelaksanaan efektifitas, efisiensi dan pengembangan manajemen serta kinerja organisasi. Banyak berpendapat bahwa perhatian ini memang selalu ada, tetapi sebenarnya hal itu lebih disebabkan karena 
keadaan seperti kompetisi ekonomi, di mana saat ini kita hidup, menjadikan 'mutu' sebagai pusat perhatian (Silva: 2007:1). Mekipun demikian apapun alasannya saat ini, mempersiapkan kualitas produk dan jasa layanan merupakan tuntutan yang tidak bisa dihindarkan terutama dalam bidang pendidikan.

Organisasi sekolah memilki tanggung jawab yang besar terhadap masyarakat pada umumnya atas apa yang mereka laksanakan. Maka dari itu sekolah memiliki tekanan yang cukup kuat untuk menaikkan tingkat kualitas kerjanya. Tekanan itu bisa berasal dari dalam atau luar sekolah. Beberapa orang berpendapat bahwa meningkatkan profesionalitas kerja dalam organisasi sekolah berimplikasi pada kommitmen kualitas, meski tanpa adanya tekanan dari pihak luar sekolah yang diyakini mampu menguatkan atau membantu dalam menciptakan kualitas tinggi dalam kerja-kerja sekolah.

Mutu pada dasarnya diperuntukan bagi organisasi perusahaan, pendekatan mutu ini telah diadopsi untuk usaha non profit seperti organisasi pendidikan. Hal itu penting karena pendidikan harus bisa mengembangkan paradigmanya sendiri tentang bagaimana memanajen mutu karena proses pendidikan itu sendiri memiliki kompleksitas yang luar biasa seperti input yang bermacam-macam, interaksi yang ada di dalamnya, dan lulusan yang dihasilkannya yang bervariasi. Setiap sekolah harus mampu memutuskan jalannya sendiri dalam peningkatan dan pengembangannya.

Mutu dipandang sebagai suatu yang melekat pada sebuah produk yang sesuai dengan kebutuhan pelanggannya. Untuk itu dalam definisi relatif ini produk atau layanan akan dianggap bermutu, bukan karena ia mahal dan eksklusif, tetapi ia memiliki daya nilai misalnya keaslian produk, wajar dan familiar (Salis, 2010;53). Pandangan ini lebih mirip dengan apa yang disampaikan oleh Juran bahwa mutu adalah kecocokan penggunaan produk (fitness for use) untuk memenuhi kebutuhan dan kepuasan pelanggan
(Nasution, 2001:15). Kecocokan penggunaan produk tersebut memiliki dua aspek utama yaitu, produknya memenuhi tuntutan pelanggan dan tidak memiliki kelemahan. Inilah konsep mutu yang tidak terlalu muluk-muluk dan tidak menarget 'mutu tinggi', sehingga dengan demikian memungkinkan setiap orang, baik yang mampu atau tidak mampu 'membeli' mutu tinggi, dapat tetap merasakan pelayanan mutu. Secara lebih sederhana konsep mutu kemudian diinterpretasikan oleh ISO 9000 sebagai suatu perpaduan antara sifat-sifat dan karakteristik yang menentukan sampai seberapa jauh keluaran/mutu barang/lulusan dapat memenuhi kebutuhan pembeli/pemakai lulusan (Bambang, 2000:41).

Berdasar atas uraian di atas konsep mutu yang dimaksud dalam tulisan ini adalah konsep mutu relatif yang dipaparkan oleh JM. Juran dan Edward Sallis di atas atau konsep mutu yang disampaikan oleh Crosby dan ISO 9000. Artinya dalam proses pengelolaan sekolah, sekolah tidak harus mengeluarkan biaya maupun tenaga ekstra untuk mencapai mutu yang bernilai mahal dan eksklusif, tetapi ia perlu menunjukkan keaslian dan kewajaran sifat-sifatnya serta keefektifannya sesuai dengan tujuan, tuntutan dan kebutuhan masyarakat masa kini dan masa datang. Terkait layanan maka, untuk memperoleh mutu yang diharapkan selain memperhatikan input, maka layanan harus ditingkatkan terutama dalam proses pembelajaran untuk dapat menghasikan keluaran atau output dan outcome yang kompetitif.

5. Layanan Prima Dalam Meningkatkan Mutu Pembelajaran

Pentingnya palayanan prima dalam meningkatkan mutu pembelajaran akan menjadikan siswa memiliki kompetensi yang lebih baik. Hal tersebut sesuai dengan hasil penelitian yang telah dilakukan dalam rangka mencapai mutu pembelajaran yang baik si SMA Al Izzah kota Batu. Adanya klinik belajar yang merupakan salah satu layanan pendidikan yang merupakan solusi dari berbagai permasalahan terkait pembelajaran.

Permasalahan 
pembelajaran diantaranya materi kurang dimengerti/difahami oleh siswa ketika proses pembelajaran di kelas berlangsung maupun kurang dimengerti disebabkan sakit dan juga di sebabkan mengikuti berbagai kejuaraan lomba yang diadakan. (Yaqien, 2015: 64).

Proses pelaksanaan layanan klinik belajar tersebut dilakukan ketika siswa mengikuti pembelajaran di kelas dan ia belum menguasai pembelajaran yang diajarkan oleh guru. Seperti seorang siswa yang belum menguasai materi matematika, ketika siswa tersebut mengikuti materi bahasa inggris dan ia memiliki kemampuan berbahasa ingris di atas rata-rata temantemannya, maka siswa tersebut bisa meminta izin kepada guru yang mengampu bahasa Inggris, untuk menemui guru matematika dalam menyelesaikan kesulitan yang dihadapinya. Ia merasa kurang memahami materi matematika dikarenakan tidak mengikutinya selama dua minggu. Selama dua mingggu tersebut ia sibuk melakukan pelatihan khusus dalam rangka mempersiapkan mengikuti lomba tingkat nasional yang akan diikutinya mewakili sekolah yang ia tempati. Setelah lomba selesai maka ia segera menemui sang guru matematika untuk mengejar materi yang tertinggal selama dua minggu tersebut. Melalui klinik belajar itulah ia bisa mengejar ketertinggalan materi yang ia tinggalkan selama mengikuti pelatihan lomba.

Hasil dari pelaksanaan pelayanan prima tersebut diantaranya, banyak prestasi yang diraih baik prestasi akademik maupun non akademik. Seperti prestasi kejuaraan lomba yang diikuti baik tingkat lokal maupun tingkat nasional. Prentasi yang diraih dalam bidang akademik diantaranya siswanya dapat di terima di perguruan tinggi baik di dalam negeri maupun di luar negeri.

\section{Penutup}

Pembahasan terkait layanan prima dalam peningkatan mutu proses pembelajaran ini merupakan hal yang sangat penting. Setiap lembaga pendidikan sudah sewajarnya memberikan pelayanan yang terbaik pada peserta didiknya. Terlebih lagi dalam lembaga pendidikan Islam, layanan prima itu mutlak diterapkan sebagai bentuk menjalankan ajaran agama Islam. Sebagaimana sabda Rasulullah saw. yang diriwayarkan oleh Imam Tabrani. Beliau menyatakan bahwa Allah sangat mencintai jika seseorang melakukan perbuatan yang dilakukan dengan itqan (kesungguhan dan keseriusan). Melakukan dengan kesungguhan dan keseriusan merupakan salah satu bentuk melayani peserta didik dengan total atau dengan prima. Dengan memberikan layanan prima terhadap peserta didik dalam proses pembelajaran akan memberikan dampak yang positif terhadap peningkatan mutu peserta didik itu sendiri. Terlebih lagi, dengan adanya era MEA yang sangat kompetitif dalam berbagai bidang termasuk dalam hal jasa pendidikan. Dengan penerapan konsep layanan prima di setiap lembaga pendidikan, terutama pendidikan Islam diharapan akan mampu mencetak generasi yang unggul dalam segala bidang baik agama maupun umum.

\section{Daftar Pustaka}

Bambang H. Hadiwiarjo, \& Sulistijarningsih Wibisono. 2000. Memasuki Pasar Internasional Dengan ISO 9000. Jakarta: Ghalia Indonesia.

Barata, A.A. 2004. Dasar-dasar pelayanan prima. Jakarta:PT.Elex Media Komputindo

Ciputra. 2015. Pelayanan Prima (www.ciputra-uceo.net). Di akses 22 Oktober 2016 pukul 09.00 wib.

Departemen Pendidikan Nasional. Manajemen Peningkatan Mutu Berbasis Sekolah. (Jakarta: 2002)

Dikdasmen, Konsep Pelayanan Dalam Pendidikan

(Http://Dikdasmenpdmkotamalang. or.id)

Dauzy, 2009. Konsep Pelayanan Pendidikan (http://dauzyinfo.blogspot.co.id) diakses 23 Oktober 2015.

KBI, Kamus Bahasa Indonesia, (http://kamusbahasaindonesia.org). 
Diakses 22 Oktober 2015 Pukul 09.50. wib

Menpan. 2003. Kemenpan Pelayanan Prima, (www.menpan.go.id) diakses 22 Oktober 2015 Pukul 09.30 wib.

Nasution, M N. 2001. Manajemen Mutu Terpadu (Total Quality Management). Jakarta: Ghalia Indonesia.

Normann. 1991. Service Management. Chicester, England: Wiley \& Son.

Nurhasyim. 2004. Pengembangan Model Pelayanan Haji Departemen Agama Berdasarkan Prinsip Reinventing Government Yang Berorientasi Pada Pelanggan di Kabupaten Gresik. Tesis. Surabaya: Program Pasca Sarjana Universitas Airlangga

Sallis, Edward. 2010. Total Quality Management in Education. Alih Bahasa oleh Ahmad Ali Riyadi dan Fahrurrozi. Jogjakarta: IRCISoD, 2010

Siagian, Riduan. 2014 Ketidaksiapan Sumberdaya Manusia Indonesia
(Http://www.analisadaily.com)

diakses ; 25 Maret 2015

Simanjuntak, M.P. 2011. Strategi Pelayanan Prima

(http://mankep.blogspot.co.id)

Diakses 23 Oktober 2015

Silva Roncelli-Voupot, 2007. Leading For Quality. National Leadership School, Ljubljana Slovenia. Bahan Review Mata Kuliah Manajemen Mutu. Pascasarjana UIN Malang.

Sutopo dan Suryanto, Adi. 2003. Pelayanan Prima. Jakarta: Lembaga Administrasi Negara Republik Indonesia.

Tim Penyusun Kamus Besar Bahasa Indonesia. 1999. Kamus Besar Bahasa Indonesia. Jakarta: Balai Pustaka.

Utomo, Eddy. 2012. Pelayanan Prima Sekolah (http://eddyutomo.blogspot.co.id) di akses 23 Oktober 2015.

Yaqien, 2015. Manajemen Mutu Layanan di SMA AL Izzah Kota Batu. (Penelitian Kompetitif: UIN Maliki Malang) 